TA-KONZEPTE UND -METHODEN

\section{The Ethics of Participatory Technology Assessment}

\author{
by Bernard Reber, Université de Paris 5
}

The purpose of this article is to analyse ethics in Participatory Technology Assessment (PTA), from two different perspectives: first from a comparison of two different processes (French citizens' conference 1998 and Swiss "PubliForum" 1999, both on genetically modified food); second from meta-level cross-European secondary evaluations, working through a specific set of criteria. Recognizing the normative aspects of PTA, it tries to combine discourse analysis and moral and political philosophy, which are very often separated mostly for institutional and frame of relevance reasons. This separation is mainly due to the famous facts/values dichotomy.

\section{Introduction}

In the case of certain technical and scientific choices, which remain controversial, resorting exclusively to the advice of experts for decision-making by political and economic leaders (i.e. TA or Technology Assessment) is insufficient to ensure a balanced judgment - even if these experts have different opinions. Nor are the resources of scientific popularization or translation for a larger public sufficiently developed, involving the communicational processes of mediation (see Dziedzicki 1998), and targeting public acceptance of large technical and industrial projects.

If the decision is in the hands of representative political decision-makers, they occasionally express their wish to broaden the spectrum of actors ready to be involved in debates on controversial technical subjects. Some analysts have called for a "technical democracy", or, in other terms, have attempted to "let the sciences enter democracy."3 On more or less reduced scales, experiments have been developed allowing the articulation between the two worlds of science and democracy, notably via Participatory Tech- nology Assessment (Reber 2007). With a wide diversity of approaches, these have opened up spaces where actors exchange their views ${ }^{4}$, deploying diverse modes of communication like narration, interpretation, argumentation, and reconstruction, to mention only these. ${ }^{5}$

At the time that pioneer analyses appeared in France on this type of project, the first comparative European evaluations of these practices were also published, such as the EUROPTA and TAMI projects or the study entitled "Governance of the European Research Area: the role of civil society". 6 Other publications have contributed to this evaluation of PTA as well. After having screened and evaluated technologies according to different modes, researchers and practitioners proceed to another, more refined evaluation of comparing the methodologies and results. These evaluations refer us back to different disciplines: among them moral and political philosophies emerge as fundamental, though they are rarely requested.

This article will focus on ethics, one of the theoretical thematic points in PTA. A comparison between the French and the European experiences and analyses reveals some interesting differences concerning the treatment of ethics at the empirical as well as the theoretical levels. Indeed, from an empirical point of view, an explicit ethics seems irrelevant (or at least absent) to the steering committee of the French citizens' conference, whereas it is given an important place in the Swiss PubliForum or in other European experiments. Nevertheless, aside from defining the rules, in the French conferences some events unforeseen by the organizers emerge, or messages from cybercitizens on forums, dedicated to these conferences, introduce their own type of specific questioning (Reber 2006c).

At a second, more theoretical level, the cross-European evaluation of the EUROPTA project presents ethics and the question of norms as much for justification as for the orientation of PTA managerial procedure. The place of ethics in the analyses is less frequent in French analysis compared with the other European countries. If the time has arrived for European crossevaluation of this type of innovative procedure in participatory and deliberative public debates, simply to answer the question "What is a good debate?" or to justify the application of these 
procedures in tackling scientific and technological questions, it is hard to dodge basic normative and epistemic problems. In human and sociological studies as much as in other domains, they underlie the choices of description and norms. This article will, finally, open up these perspectives in our conclusion by posing some philosophical questions, both political and moral, and articulating them with objects of research in scientific studies. A research program at CNRS matching questions from the "hard" sciences with others from the human and social sciences (see part 3).

\section{Ethics in PTA Projects}

Our research starts the long work of comparing the different conferences with regard to "how they progress" astride between sociology and philosophy, before venturing into the area some persons call moral (or ethical) sociology (Pharo 2004, Bateman 2004). It shall not, indeed, be content with comparative analyses of the procedures, as if these techniques were not also subject to the ambivalence which is inherent in the nature of technical objects. As for a short-sighted pragmatism or an ethnomethodology which would merely touch on moral aspects at its surface, neither will ultimately be satisfying. A quick analysis of the possible ethical aspects which have emerged and sometimes might have been shunted aside during real consensus conferences will mark the beginning of the analysis.

In comparing both the French citizens' conference (1998) and the Swiss PubliForum on genetically modified (GM) food (1999), it can be discovered that the place of ethics is not the same. In the French conference, the steering committee have not mentioned ethics, perhaps because they were alleging from the start a necessary neutrality on the part of its experts and 14 (one has left during the debate) citizens who were moreover collectively referred to as "candide". This surprising qualification means that they have not special interest regarding GM food and come from the general public. The neglect of any specific reference to ethics was remarked upon by certain French citizens on a dedicated website on the Internet, where they felt it should have been part of the conference's job to formulate ethical judgments. In Switzer- land, on the contrary, experts and citizens were sometimes engaged in debating questions of ethics from the very beginning. An ethicist was member of the steering committee, which was larger than the French one (15 in Switzerland and six in France). As the citizens had been recruited by way of the press, those who joined in the debate were often those who had strong feelings on the subject. The concern was thus rather to guarantee a certain pluralism, even by enlarging the debate to include an international aspect with foreign experts invited.

Regarding ethics in particular, the Swiss PubliForum included a round table discussion entitled: "What ethical and moral judgment do you have concerning genetically modified food?" Three "reference persons" were then able to develop their arguments on the basis of which the citizens presented their recommendations. As a first step this normative way of taking a position will be discussed and the weakness of the arguments from an ethical point of view will be indicated. We shall, however, be satisfied with making the following comments:

In the first place, the brevity of the analyses offered during the conferences and their superficiality for founding an ethical debate were noted by one of the experts as well as in the Swiss citizens' report, which emphasized the need for deepening the questioning on the topic at hand. Secondly, a link can established between these specifically ethical questions and the Swiss popular initiative on genetic protection in 1998, which was rejected, but was an occasion of numerous public debates. To express a faint disagreement with what some French experts wrote (Callon et al. 2001), the claim of the 1998 popular initiative was not so much a question of forbidding transgenetic researches but a demand for good ethical reasons for developing them ${ }^{7}$.

The analyses of the French citizens' conference show that the neutrality of the expertise, which the organizers had considered as guaranteed, was called into question in an unexpected way and became one of the minor controversies as well as a major issue at the conference. The question of neutrality was discussed in a special moment before the last round table. The debate took an explicitly ethical turn - at least certain actors claimed it did - when, in their introductory speeches the president of the Office Parlementaire d'Evaluation des Choix Scientifiques 
et Technologiques (OPECST) and a civil servant repeatedly asserted that "the experts are the most neutral possible".

In the heat of the debates the experts occasionally harangued the citizens to "face up to their responsibilities", they even allowed themselves "personal opinions" or preached the inevitable character of this or that scientific advance. A significant reversal of gears occurred when one of the researchers put the citizens on the podium in the experts' stead by asking: What could you suggest to help us make better decisions?

As far as the citizens' panel was concerned, it should be noted here that the citizens were not as neutral regarding GM food as the criteria for selection proclaimed. One was a breeder of pigs and another the wife of a cereal farmer. When the discussion tended to incriminate the farming industry, they rose of a single accord to "defend the family" by trying to propagate themselves as simply the executants for a "superior demand".

\section{Evaluation and Criteria for Good PTA}

We can now deal with the makeup and the management of these procedures, as they have been designed by TA offices, and consider some efforts to evaluate them on the basis of different lists of criteria.

\subsection{A First Evaluation of Public Participa- tion Studies: Parallel Comparison of Available Literature}

Evaluations are mostly concerned with the extent of public participation, notwithstanding the reservations mentioned above. Analysis will concentrate on those authors who classify diverse PTA experiments. Among the reference works in this domain, two often quoted articles should be mentioned. The first is signed by Gene Rowe and Lynn J. Frewer and the other by D. Fiorino (Rowe, Frewer 2000; Fiorino 1990). The frame of evaluation proposed by Rowe and Frewer claims to go farther than the first attempts of Lowndes et al. (1998), Fiorino (1990), Crosby et al. (1986), Lynn and Busenberg (1995), Smith et al. (1997), Webler (1995) and Renn et al. (1996), who are all interested more in what makes for an effective process than in measuring its results, preferring an approach that is "procedural rather than substantive." Rowe and Frewer, therefore, work on determining criteria which would allow them to estimate the success of public participation according to the devices analysed. They avoid limiting themselves to ad hoc suggestions or a critical appreciation of the advantages and inconveniences of different techniques only.

Their criteria of evaluation can be divided into two classes: criteria concerning public acceptance and those concerning the quality of the processes chosen.

Table 1: Criteria to estimate the success of public participation (according to Rowe / Frewer 2002)

\begin{tabular}{|l|l|}
\hline $\begin{array}{c}\text { Class 1: } \\
\text { Concerning public } \\
\text { acceptance }\end{array}$ & \multicolumn{1}{c|}{$\begin{array}{c}\text { Class 2: } \\
\text { Concerning the quality } \\
\text { of the process }\end{array}$} \\
\hline representativeness & $\begin{array}{l}\text { accessibility of informa- } \\
\text { tion }\end{array}$ \\
\hline independence & definition of the tasks \\
\hline early commitment & $\begin{array}{l}\text { structuralization of the } \\
\text { decision }\end{array}$ \\
\hline influence & $\begin{array}{l}\text { cost/efficiency balance of } \\
\text { the operation }\end{array}$ \\
\hline transparency & \\
\hline
\end{tabular}

Source: presentation by Reber

The results established by the systematic application of these criteria are then presented on a chart, with an approximate "high" and "low" score according to the types of procedures used. Rowe and Frewer argue that evaluations of this sort are rare because the exercise is difficult, most cases boiling down to an evaluation of the efficiency of the procedures. Nevertheless, they intend to propose a frame or a normative model in spite of the fact that their evaluation was made "on the basis of their opinion as a measure of evaluation", a precarious and subjective system of measurement to say the least! Rowe and Frewer recognize as well that they made no effort to organize their criteria according to a hierarchy of importance, which leaves the methodology open to questions concerning both the implementation as well as the management of a process and its evaluation. 
Just as might have been expected, the consensus conferences obtained the best scores on the basis of the criteria developed by them, notwithstanding their high cost. However, Rowe and Frewer recognize that the frame of reference they offer for discussion has the limitation of relying on the suggestions of other researchers and practitioners rather than on the analysis of empirical cases.

\subsection{Dialogic Democracy as Normative Frame}

Having observed the limitations of an approach that contents itself with using procedures analysed in reviews or studies, we are ready to discover the real "flesh and blood" life-size experiments that do exist. To mention only the French ones, there are the studies financed within the program "Deliberation, Decision, Environment" (DDE), launched by the French Ministry of Ecology and Sustainable Development, which was finished in 2005 . The article by Rowe and Frewer was further exploited by the collective work co-signed by Michel Callon, Pierre Lascoumes and Yannick Barthe, which is often quoted and sometimes criticized in DDE (Callon et al. 2001). Astonishingly, the aim announced by its authors is "not to make an inventory of procedures but to propose a guideline for evaluation". The proposition, in so doing, reaches beyond the French context even though it applies there first of all.

Callon et al. in their attempt to justify the need to make a comparative evaluation of devices and procedures, refused to describe the French series of experiments in any detailed or exhaustive way. ${ }^{8}$ In a more narrative manner than Rowe and Frewer, Callon et al. put questions of technology evaluation within the framework of the sociology of sciences and technologies. With the very pragmatic concern to "follow the actors" onto their terrain, they nonetheless interspersed their story with charts and tables to estimate the different procedures. Some of the criteria they relied on were those of Rowe and Frewer, and their index of appreciation, like theirs, went from high to low (or weak to strong).

Diagrams are produced to illustrate comparisons along these lines, but they require interpretation by two other tables to be under- standable. 0ne traces a trajectory showing confined and "open air research cooperating" in adapting laboratory products to a wider culture, leading to collective research identifying and formalizing the problems encountered. The other concerns the "investigation of the collective" on a chart crossing the individuals' aggregation in a common group with the assertion, mutual consideration and negotiation of their "identities". The first table refers back to theories of translation (in French "traduction") that are famous in Science Studies, the second, which is also in use there, has an additional prestige from the role it plays as an index in political science or the sociology of identities. Both tables indicate cleavages such as allow for "delegations" that the authors intend to question. For the clarity of the text, let's call the first delegation scientific and the second political.

The first of these cleavages served to isolate those experts charged with producing a hard and certain brand of science, seen as guaranteed knowledge like "the hardest granite." The second widens the gap between ordinary citizens and the professional politicians supposed to represent them. Both these "delegations" are devices permitting what is recognized as a justifiable good, even if it is paradoxical and bought at the price of the silence of citizens, making it seem inappropriate to ask two basic questions: What do we know about the world? What is our collective society made up of?

Against this theoretical backdrop, the evaluation of the procedures will accordingly be made with regard to "their capacity to facilitate the deepening of a democratic regime and consequently to overcome the limits which respect for the double delegation imposes on it." The mentioned criteria can be considered as comprising three elements in a first group: intensity, openness, and quality, along with their sub-criteria because both "delegations" have to be considered (cf. table 1).

1. The intensity, or the depth it involves here, is proportional to its questioning of both cleavages in the double "delegations". Two subcriteria thus appear determining: for the first "delegation" (scientific), how early the laypeople become committed in the procedure and thus in the research investigating "the possible worlds"; in the second delegation 
(political), how far the collective entity can go in its concern to "negotiate identities".

2. Three sub-criteria further define the openness qualifying for speech, exchange and negotiation, as follows: the variety of the groups consulted, their degree of independence with respect to the established actors, and their control over how representative they remain taking into account the modifications that may occur with time.

3. The quality of the exchanges is to be appreciated according to the seriousness of the discourse (its coherence, accuracy and relevance) and its more or less far-reaching effects.

This first list of criteria constitutes "the normative space" (p. 218) inferred by the dialogical procedures. It is no longer simply a question of "following the actors in their work of elaboration." (p. 136, 210, 263). Also, other criteria would allow an appreciation of how the procedures are applied. The procedures involve an accounting of the equality of access to the debates, their transparency and traceability as well as an assessment of the rules governing their organization.

Equipped with this "battery of criteria" the authors can then review some PTA procedures. The citizens' conference, and this only, is subjected to evaluation with the afore-mentioned criteria. It should be noted here that, as far as Callon et al. are concerned, the notion of "hybrid forum should not be reduced to the question of procedures." (p. 261). This refers back to the less convenient comparative evaluation.

An earlier collection of articles compares theoretical approaches and different typical procedures of Participative Technology Assessment by appealing to authors of various nationalities who are, for the greater part, experienced practitioners in the area (Joss 1999). Limitations of time and space forbid a detailed presentation and critics of their analyses here (see Reber 2005). But it is interesting to discover, in these other authors, openess to new standards for theories of democratic procedural justice, communicational theories, and views on modernity (Barber, Beck, Giddens, Habermas, Luhmann). Already at present level can be noted that Callon et al., even if they denigrate research in political philosophy (p. 27, 210), they nonetheless use it, at least in footnotes. We wonder if their project has to do with the sociology of science or has as its object putting theories of democracy on trial. Again, from a theoretical point of view, another essay, culled from years of collective work, The Politics of Nature by Bruno Latour, approaches the normative function of these studies more directly (Latour 2004).

After these attempts at reformulating theories of democracy - in fact summarizing them, but always in the context of public scientific controversies - we intend to further explore the political philosophies expressed in the debates, which are often obsessed with the recognition of identities or questions of distributive justice, but blind to scientific and technical problems. The sole exception in this regard is Hans Jonas who poses uncomfortable questions about which public policies determine the organization and orientation of dialogue and debate in the public arena. ${ }^{9}$ In the area that concerns us here, the analysis of empirical devices sheds light on questions that spring up with the emergence of political philosophy, as for example with the opposition between pluralism and neutrality, or with the founding of a National Committee for Public Debate in the wake of discussions around the precautionary principle. ${ }^{10}$

Callon et al., to take their example alone, head toward a dead-end when they proclaim that a political philosophy is useless and they can do without it. ${ }^{11}$ On the other side, authors in philosophy as is the case with Jean-Pierre Dupuy ${ }^{12}$, are not very helpful. There is a thin line to tread between a merely abstract approach and one which strives to be anti-theoretical and explicitly anti-philosophical, but which nonetheless relies furtively on authors who are in fact political philosophers, whenever there is a need to justify delicate theoretical positions. Philosophers willing to confront the empirical and moral implications of these devices are all too rare, it is true. They may find the point of view of Sirius or from nowhere less demanding, or keep to the subsidiary regions of bioethics or environmental ethics, not attaching great importance to social and political mediations. From this point of view Armin Grunwald's work (Grunwald 1999) or studies like the INES Project ${ }^{13}$, in their effort to circumscribe objectives for research specializing in ethics and PTA, seem to me more fruitful. We might add to this a broader perspective incorporating the political 
questions we have just evoked. Nevertheless, it is not the political questions inherent in philosophy that we intend to focus on here, but the resources of moral philosophy.

\subsection{Ethics in PTA Process Management}

By another route, the European one, the important place of ethics is reasserted: in the crossevaluation of the EUROPTA project. In their introduction, the assessment team, indicates as their first objective the formation of theoretical and analytical framework on the role and the function of PTA, "as a basis of normativeconceptual discussion and empirical analysis" (p. 7). In their report, an important chapter by Lars Klüver is entitled "Project management: A matter of ethics and firm decision" (Klüver 2003). Ethics is treated by this specialist of PTA, who is a member of the Danish Board of Technology, within the framework of the processes of management of PTA. The gap between the procedures announced and the real progression of the processes, between macro-social problems (national culture, institutions, projects) and personal interactions, the evaluation of PTA behaviour at the process level as opposed to its proclaimed goals are all explained in ethical terms. Klüver, in his own theorization, proposes a model drawn on the lines of discourse ethics. This may demand long debates. He distinguishes between the Habermassian ideal of a "master-free dialogue" to approach "the truth" (p. 88-89) and a practical discourse ethics "more or less synonym to democracy". Discourse ethics in project management, according to him, is more instrumental in the case of PTA. In practice, nevertheless, where relationships enter, idealistic ethics and instrumental discourse merge.

Compared to TA, which is more utilitarian, PTA should be qualified by an extension of the spectrum of knowledge as well as the extension of norms and of the values brought into play. The personalizing of opinions is at the same time a factor to be taken into account for participation and a vector for the normative impulse. Moreover, there is a very fine borderline between cognitive and normative aspects in this kind of communication process.

Hoping to supply an operational system of ethical evaluation with which to review the experiments of the EUROPTA project, Klüver formulates the following desiderata of what he calls discourse ethics:

- the aim of equality which strives to give equal power to every participant,

- the degree of light shed by appropriate information,

- loyalty in interpersonal relations,

- a flexibility admitting the limitations of a single point of view and allowing participants to make their own agendas,

- authenticity through clear communication so that the need for interpretation is minimal,

- transparency ensuring that formal rules are known and adhered to by all participants,

- legitimacy due to the fact that all parties touched by a problem discussed are invited to the dialogue.

As a PTA practitioner, Klüver recognizes that all these points are rarely observed in reality. However, this fact should not be used as an excuse for avoiding the effort to improve PTA by taking into account the requirements of discourse ethics.

\section{Conclusion: The Place of the Implicit Moral Theories of the Actors}

The European and French comparative projects on the procedures and processes of PTA that are being developed at present seem to be belatedly discovering the need to face normative problems. It was indeed out of the need to make far-reaching decisions, along with the concomitant need to give them legitimacy, that State authorities evolved new, hybrid, legally unclassifiable structures to deal with the problems. A new awareness of risks accompanied by public debate gave them their impetus. The justifications they turned to were founded on moral considerations, frequently hinting at a Habermassian ethics. Nor is the latter the only feasible theory. One could for instance have turned to a kind of Rawlsian, or Audi's (Audi 2004) ethics, or have been inspired by John Dewey or, better, by the richness of moral and political philosophy.

Finally, the lists of criteria offered by proponents of the "scientific method" - lists which could be expanded ad libitum - are insufficient in solidity, especially on the moral side of argu- 
mentation to incite us to look for more stable characteristics such as those offered by moral philosophy. The program pursued as Recherche Permanente at the Centre National de la Recherche Scientifique (CNRS), which has as its object discourse analysis and moral philosophy, we hope to break new ground. One way of doing this could be to track down the implicit moral theories of the different actors. Approaching ethics from a new direction, which is not purely normative nor in line with the Habermassian ethics of discourse engaged in the justification and management of procedures, we mean to examine styles of argumentation taken from moral philosophy and used for purposes of justification, where the style remains but the overt references have disappeared.

Deliberative democracy, true enough, depends on theoretical authors who have to integrate communicational requirements, reinterpreting linguistic terms (that are not merely linguistic), as does Habermas, without submitting to empirical testing. All of this makes for excessive idealism, a lack of polemics and a very narrow frame of reference. It should be possible at present for the researcher in human and social sciences to apply these theoretical frames to real empirical discourses, or to detect an unformulated theory, deflected by a linguist pursuing other objectives than a philosophical one. A space exists for a community of researchers mobilized around theories of argumentation. Our present project at the CNRS has, hopefully, contributed to such a program by indicating the potential development and virtual importance of moral (implicit) theories (Reber 2006b). The evaluation of PTA procedures and process from the point of view of moral philosophy at grips with the descriptive sciences has allowed us to analyse the articulation between real speech and normative democracy, on the occasion of public scientific controversies around the precautionary principle, seen as originating heretofore unforeseen problems.

\section{Notes}

1) This text is a shorter version of the presentation given at the conference "Ethics in Participatory Technology Assessment" in July 2003, organized by the Institute for Technology Assessment and Systems Analysis (ITAS) at Karlsruhe Re- search Centre. I wish to express my thanks to the research unit, and here especially to Gotthard Bechmann, Dr. Armin Grunwald, and Frank Fischer who invited me to speak. For more detailed and deeper versions see Reber 2004, Reber 2005, Reber 2006a and Reber 2006d.

2) This was articulated by Sclove 1995 , Kleinman 2000, Fischer 2000, Fischer 2003, Callon et al. 2001 and de Cheveigné et al. 2002.

3) See Latour 1999 or Habermas 1968 in his first period.

4) Some researches pay attention to the manner in which data bases are build up by analyzing the computer technologies and communication techniques used in these procedures, whether through imagery projected on the screen, cyber cards or sophisticated software for simulation purposes (see for example Latour 2005).

5) To use the categories proposed by Ferry 1991.

6) The EUROPTA project ("European Parliamentary Technology Assessment: Methods of participation in evaluation and decision-making on technological matters", 1998 / 1999) was a project of the European Commission and was coordinated by the Danish Board of Technology along with Austrian, German, Dutch and British partners and Swiss associates (see Joss, Belluci 2003). Quotations refer to PDF version: http://www.tekno.dk/subpage.php3?article $=345$ \&language $=$ uk\&category $=11 \&$ toppic $=$ kategori 11. TAMI ("Technology Assessment in Europe: Between Method and Impact") is a further project financed by the European Commission, (Strategic Analysis of Specific Political Issues; see Decker, Ladikas 2004). Further information about the last mentioned analysis which was concerned with the role of civil society, can found be at http://europa.eu.int/comm/research/ science-society/documents en.html.

7) The popular initiative "Für Lebensmittel aus gentechnikfreier Landwirtschaft", which was largely accepted (27.11.2005), is much more restricted (see: http://www.parlament.ch/f/home page/wa-wahlenabstimmungen/wa-va-volksab stimmungen/wa-va-20051127/wa-va-20051127gentechfrei.htm).

8) For detailed analyses, specifically focused on ethical questions in three cases of consensus conferences see Reber 2006a, Reber 2006d and Reber 2004.

9) Quite at odds with a number of French commentators on the Principle of Responsibility, Jonas took care to indicate the difficulties which these questions would meet in terms of public policies (see Jonas 1991, pp. 31-32).

10) France was equipped with these new and original structures for public debate at the beginning 
of the so-called "Barnier" laws of 1995, which grounded their legitimacy among other things on the two basic principles of precaution and participation (see: http://www.debatpublic.fr/ cndp/debat_public.html)

11) "The open air philosophy practiced by the Danes, the Dutch and the Japanese, is worth all the stuffy political and moral philosophies one finds on American campuses and other selfenclosed spaces, to the point of indigestion." (Callon et al. 2001, pp. 26-27 )

12) As a "rationalist extremist" the urgency is for him "conceptual before being moral or political.” (Dupuy 2002, p. 24, p. 13). "Before imagining political and technical procedures which would allow a technical and scientific democracy to envisage what it wishes to accomplish (....) we need to define the nature of the evil we are faced with." (ibid., p. 21-22) As a sceptic with regard to collective rationality, particularly as regards its procedural and deliberative aspect, Dupuy caustically took a swipe at the Prime Minister's Report on the precautionary principle under the direction of Kourilsky and Viney whom he styles "post-modernists" still resigned to using collective procedures. Nore is he more kindly inclined toward sociologists of the "hard" sociology or history of sciences (ibid. p. 23). (See Kourilsky, Viney 2000).

13) INES is the acronym of "The Institutionalisation of Ethics in Science Policy: Practices and Impacts" see: http://www.cesagen.lancs.ac.uk/ research/related/ines.htm.

\section{References}

Audi, R., 2004: The Good in the Right. A Theory of Intuition and Intrinsic Value, Princeton, Princeton University Press

Bateman, S., 2004: L'expérience morale comme objet sociologique. In: Pharo, P. (dir.): Ethique et sociologie: perspectives actuelles de la sociologie morale. L'Année sociologique 54/2 (2004), pp. 389-412

Callon, M.; Lascoumes, P.; Barthe Y., 2001: Agir dans un monde incertain. Essai sur la démocratie technique. Paris: Seuil

Crosby, N.; Kelly, J.-M.; Schaefer, P., 1986: Citizens panels: A new approach to citizen participation. In: Public Administration Review. 46/2 (1986), pp. 170-178

de Cheveigné, S.; Boy, D.; Galloux, J.-C., 2002: Les Biotechnologies en débat. Pour une démocratie scientifique. Paris: Balland
Decker, M.; Ladikas, M. (eds.), 2004: Bridges between Science, Society and Policy; Technology Assessment - Methods and Impacts. Berlin: Springer

Dupuy, J.-P., 2002: Pour un catastrophisme éclairé. Quand l'impossible est certain. Paris: Seuil

Dziedzicki, J.-M., 1998: La Médiation environnementale: une comparaison internationale. ESAEDF-DER, Rapport HN-55/98/046

Ferry, J.-M., 1991: Les puissances de l'expérience Le sujet et le verbe. Les ordres de la reconnaissance. Paris: Cerf, 2 tomes, 2 vol.

Fiorino, D.J., 1990: Citizen participation and environmental risk: A survey of institutional mechanism. In: Science, Technology \& Human Values. 15/2 (1990), pp. 226-243

Fischer, F., 2000: Citizens, Experts and the Environment: The Politics of Local Knowledge. Durham: Duke University Press.

Fischer, F., 2003: Reframing Public Policy. Discursive Politics and Deliberative Practices. Oxford: Oxford University Press.

Grunwald, A., 1999: Technological assessment or ethics of technology? Reflections on technology development between social sciences and philosophy. In: Ethical Perspectives, Journal of the European Ethics Network 6/2 (1999), pp. 170-183

Habermas, J., 1968: Technik und Wissenschaft als „Ideologie“. Frankfurt a. M: Suhrkamp

Jonas, H. (1979), 1991: Le Principe responsabilité. Une éthique pour la civilisation technologique. Paris: Cerf

Joss, J. (ed.), 1999: Special Issue on Public Participation in Science and Technology. In: Science and Public Policy 26/5 (1999), pp. 290-373

Joss, S.; Belluci, S. (eds.), 2003: Participatory Technology Assessment. European Perspectives. London: Centre for the Study of Democracy and Swiss Centre for Technology Assessment

Kleinman, L. (ed.), 2000: Science, Technology \& Democracy. New York: State University Press of New-York

Klüver, L., 2003: Project management: A matter of ethics and firm decision. In: Joss, S.; Belluci, S. (eds.): Participatory Technological Assessment. European Perspectives. London: Centre for the Study of Democracy and Swiss Centre for Technology Assessment

Kourilsky, P.; Viney, G., 2000: Le principe de précaution. Paris: Odile Jacob - La Documentation française

Latour, B., 2004: Politics of Nature. How to bring the sciences into democracy. Cambridge: Harvard University Press 
Latour, B.; Weibel, P. (eds.), 2005: Making Things Public. Atmospheres of Democracy. Cambridge: ZKM and MIT Press

Lowndes, V.; Stocker, G.; Pratchett, D. et al., 1998: Enhancing public participation in local government: A research report. London: Department of the Environment, Transport and the Regions

Lynn, F.M.; Busenberg, G.J., 1995: Citizen advisory committees and environmental policy: What we know, what's left to discover. In: Risk Analysis 15/2 (1995), pp. 147-162

Pharo, P., 2004: Morale et sociologie. Le sens et les valeurs entre nature et culture. Paris: Gallimard

Reber, B., 2003: Les controverses scientifiques publiques au secours de la démocratie. In: Cosmopolitiques. Cahiers théoriques pour l'écologie politique, 3 (2003), pp. 93-107

Reber, B., 2004: Ethique et évaluation technologique participative. In: Castagna, B.; Gallais, S.; Ricaud, P. et al. (eds.): La situation délibérative dans le débat public. Tours: Presses Universitaires François Rabelais et Maison des Sciences de l'Homme "Villes et Territoires", Vol. 2 (2004), pp. 387-405

Reber, B., 2005: Technologies et débat démocratique en Europe: de la participation à l'évaluation pluraliste. In: Revue Française de Science Politique 55/5-6 (2005), pp. 811-833

Reber, B., 2006a, forthcoming: Théories morales et Cosmopolitiques. L'épreuve de l'évaluation technologique participative. In: Lolive, J.; Soubeyran, O. (eds.): Émergence des Cosmopolitiques et refondation de la pensée aménagiste. Paris: Centre Culturel International de Cerisy-la-Salle, La Découverte

Reber, B., 2006b: Pluralisme moral: les valeurs, les croyances et les théories morales. In: Archives de philosophie du droit, Tome 49, pp. 21-46.

Reber, B., 2006c, forthcoming: Evaluation technologique participative et promesses de la démocratie électronique. In: The Innovation Journal

Reber, B., 2006d, forthcoming: The precautionary principle: meeting the test of citizens' conferences on the subject of GMOs. In: Science Communication. An Interdisciplinary Social Science Journal

Reber, B., 2007, forthcoming: Technological Assessment as Policy Analysis. From Expert Advice to Participatory Approaches. In: Fischer, F.; Miller, G.; Sidney, M. (eds.): Handbook of Public Policy Analysis. New-York: Rutgers University Press

Renn, O.; Webler, T.; Kastenholz, H., 1996: Procedural and substantive fairness in landfill siting: a Swiss case study. In: Risk: Health, Safety and Environment, pp. 145-168

Rowe, G.; Frewer, L.J., 2000: Public Participation Methods: A Framework for Evaluation. In: Sci- ence, Technology and Human Values, 25/1 (2000), pp. 3-29

Rowe, G.; Frewer, L.J., 2004: Evaluating public participation exercises: A research agenda. In: Science, Technology \& Human Values, 29/4 (2004), pp. 512-557

Sclove, R., 1995: Democracy and Technologies, New York: Guilford Press

Smith, L.G.; Nell, C.Y.; Prystupa, M.V., 1997: The converging dynamics of interest representation in resources management, Environmental Management 21/2 (1997), pp. 139-146

Webler, T., 1995: "Right" discourse in citizen participation: An evaluative yardstick. In: Renn, O.; Webler, T.; Wiedemann, P. (eds.): Fairness and Competence in Citizen Participation: Evaluating models for environmental discourse. Dordrecht: Kluwer Academic, pp. 35-86

\section{Contact}

Dr. Bernard Reber

Recherche Permanente au Centre National de la Recherche Scientifique (CNRS)

Centre de Recherche Sens, Ethique, Société (CERSES)

CNRS-University Paris 5

CERSES-CNRS

Centre universitaire des Saints-Pères

45, rue des Saints-Pères, 75270 Paris Cedex 06, France

Tel.: +33 - 3 - 88605584

E-Mail: bernard.reber@univ-paris5.fr 